\title{
Asia-Pacific tourism futures emerging from COVID-19 recovery responses and implications for sustainability
}

\author{
Susanne Becken and Johanna Loehr
}

\begin{abstract}
Purpose - The purpose of this paper is to provide contrasting narratives of what the future of Asia Pacific tourism may look like, and to identify how current policy interventions and recommendations made for coronavirus disease 2019 (COVID-19) recovery shape the system's trajectory.

Design/methodology/approach - Drawing on a set of four possible futures emerging from COVID-19, tourism policy responses are analysed and a link to their potential contribution to the Sustainable Development Goals is made.

Findings - A system goal is presented for each scenario, and what this means for the tourism system. Existing policies indicate that tourism is moving towards a "Discipline" future, although evidence for all four trajectories could be identified. Whilst the "Transform" scenario is most aligned with a sustainable future, the findings highlight that sustainability outcomes are possible in the other scenarios as well, if risks are managed adequately.

Research limitations/implications - The limitation is that the core structure of the four futures was not specifically developed for tourism. However, given that tourism is firmly embedded in national and global economies, this limitation is not material.

Practical implications - This paper supports decision-makers to develop adaptability in the face of great uncertainty and complexity. Risks and opportunities associated with each of the four tourism futures are identified, and examples are provided how sustainability outcomes can be maximised in each.

Social implications - Sustainability is a safe and necessary strategy regardless of the trajectory to any of the four scenarios. The long-term health of the tourism system and anyone involved in it depends on significant progress along the Sustainable Development Goals.

Originality/value - This paper explores pathways for system change and how different COVID-19 policy approaches contribute to shaping the system's trajectory. It highlights the risks associated with certain trajectories, and also identifies how short-term recovery priorities might undermine long-term sustainability.
\end{abstract}

Keywords Scenarios, COVID-19, Transformation, Systems thinking, Policy responses, Sustainable Development Goals

Paper type Research paper

\section{Introduction}

The coronavirus disease 2019 (COVID-19) pandemic has devastated global tourism, but it also presents "... an opportunity for transformation with a focus on leveraging its impact on destinations visited and building more resilient communities and businesses through innovation, digitalization, sustainability, and partnerships" (UN, 2020, p. 2). Whilst aspirations are high, the future of tourism is uncertain, and transformation is by anyone's definition (e.g. Nalau and Handmer, 2015) not an easy undertaking. As the pandemic is still unfolding, it is too early to predict what the ultimate outcome for tourism will be. There continues to be considerable debate as to whether the recovery of tourism involves a substantial redesign of the tourism system or more of
Susanne Becken and Johanna Loehr are both based at the Griffith University-GC Campus, Southport, Australia.

Received 28 May 2021 Revised 6 September 2021 11 January 2022

Accepted 15 January 2022

(C) Susanne Becken and Johanna Loehr. Published in Journal of Tourism Futures. Published by Emerald Publishing Limited. This article is published under the Creative Commons Attribution (CC BY 4.0) licence. Anyone may reproduce, distribute, translate and create derivative works of this article (for both commercial and non-commercial purposes), subject to full attribution to the original publication and authors.

The full terms of this licence may be seen at http://

creativecommons.org/licences/ by/4.0/legalcode

The authors thank the ADB for their support.

Funding: This article draws on a project funded by the Asian Development Bank (ADB, 2021), but the findings presented here are new. 
a "return to the old normal" (Assaf and Scuderi, 2020; Rastegar et al., 2021; Scott, 2021). The fastexpanding volume of tourism articles on the COVID-19 crisis is evidence of the diversity of researchers' ideas, beliefs, hopes and fears (Higgins-Desbiolles, 2021).

Whilst significant changes are possible, especially after a profound shock such as the current pandemic, evolutionary economics highlights that the future is largely determined by the past, for example, through institutional lock-in or path dependency (Moyle et al., 2017). Systems continuously adapt or renew (e.g. by destroying and rebuilding from within, Schumpeter, 1942). However, change is often constrained when systems are locked into a particular trajectory (Becken, 2019; Hall, 2019). Transformation theory represents a system theory that accounts for past dynamics and rules (including government policy, business norms and consumer behaviours) but simultaneously explores opportunities and pathways for change (Moyle et al., 2017). Transformation can be a deliberate choice to improve a system or prevent its collapse (O'Brien, 2012). Some have argued that transformation is driven by social entrepreneurs who innovate and overturn unsustainable systems (Rahdari et al., 2016). Others highlight that changes in governance arrangements and policy play a central role in system change (Glass and Newig, 2019). A broad interpretation of policy is taken in this research to include any strategic document that gives direction to tourism decision-makers. This research therefore draws on pandemic responses by governments and tourism-relevant organisations, groups representing influential actors within the system, to understand the potential direction of change after COVID-19.

This paper employs a foresight approach, which according to Postma and Yeoman (2021, p. 68) "makes use of scenarios to envision multiple futures that tourism may be faced with", to explore how initial responses and recommendations regarding the COVID-19 crisis lay the foundation for four different, yet all plausible, futures. A qualitative scenario approach is used to inform contrasting narratives of the future of Asia Pacific tourism. Inevitably, these different futures reflect diverse ideologies and theories of how people interact with each other in socio-ecological systems, how they connect to their environment (e.g. see Loehr et al., 2020 on holistic perspectives), what types of governance arrangements are in place, and what the role of governments is relative to other decision-makers (Amore and Hall, 2016; Gjaltema et al., 2020). Not all approaches to policy have the same potential for transformation (Nalau and Handmer, 2015).

Of particular interest to this research is the notion of transformation for sustainability (see Patterson et al., 2015), acknowledging the multi-dimensional nature of sustainability as captured through the 17 Sustainable Development Goals (SDGs) (UNWTO and UNEP, 2017) which are agreed on globally as a guiding framework for future development that is both inclusive and within the limits of planetary carrying capacity. Whilst a detailed assessment and critique of the SDGs is beyond the scope of this paper, it is acknowledged that achieving the many goals and the 169 targets that support them is very challenging, especially given that there are trade-offs and complex interactions between the goals (Nash et al., 2020). Scenarios help understand how different futures might support sustainability, including what might unfold if particular actions are not put in place. The scenarios presented here will not cover all the implications for delivering on the SDGs, but they provide a direction of opportunities and challenges in four different futures. The key research objectives, therefore, are to examine whether 1) COVID-19 responses and recommendations drive the system towards a particular future, and 2) what this means for the sustainability of tourism in the Asia Pacific region.

\section{Approach}

This research uses two different inputs. First, the work by Forum for the Future (2020) on the Future of Sustainability was adopted as the foundation for the four tourism scenarios. Drawing on stakeholder interviews and workshops and using various methods for system mapping, Forum for the Future had identified five key dynamics (defined as clusters of trends and akin to driver analysis). These were biosphere breakdown, economic crisis and reform, tech and governance nexus, equitable transitions and regenerative openings. These drivers interact, and are influenced by 
COVID-19 response measures, to form four plausible futures emerging from the pandemic (Table 1) (Travalyst, 2021). The tourism literature confirms that these drivers and futures are highly pertinent for tourism (e.g. Buckley et al., 2015). However, what each scenario means requires further examination, including what the system goal and its underlying assumptions are for each scenario (Meadows, 2008), and how this affects the system elements of government, private sector, consumers and the socio-ecological environment.

Second, these scenarios were anchored in the context of the current coronavirus crisis to consider tourism pathways. To this end, the research examined policy responses, strategies and recommendations made regarding COVID-19 response and recovery measures (see ADB, 2021). The focus was on Asia Pacific, one of the fastest growing tourism regions globally before the pandemic, and one of the most affected in terms of travel restrictions since the start of the pandemic. Responses were identified using relevant documents and policy databases that were released by governments, regional and global organisations that are either directly involved in policy-making or are widely seen as influencing policy through guidance (e.g. the Organisation for Economic Co-operation and Development (OECD)). Documents were deemed relevant as long as they were directly relevant to the future of tourism in Asia Pacific and included, for example, regional impact and response reports (e.g. ILO, 2020; SPTO, 2020), sectoral reports (e.g. CAREC and ADB, 2021) and national recovery strategies (e.g. Department of Tourism Vanuatu, 2020). The timeframe of analysis was between April 2020 and February 2021. In total, 17 documents and 2 databases compiling COVID-19 policy responses (see Table 1) were identified via a Google search and analysed for evidence that points towards any of the four futures.

One limitation of the approach is that the core structure of the four futures was not specifically developed for tourism. However, given that tourism is firmly embedded in national and global economies, this limitation is not material.

\begin{tabular}{|c|c|c|}
\hline Organisation & Focus of publication & Date \\
\hline UNWTO Database & COVID-19: Measures to Support Travel and Tourism & $\begin{array}{l}\text { Set up in } \\
2020\end{array}$ \\
\hline UNEP, IMF and GIZ Database & Global Recovery Observatory & $\begin{array}{l}\text { Set up in } \\
2020\end{array}$ \\
\hline ILO & Tourism workforce and employment & Apr-20 \\
\hline $\begin{array}{l}\text { One Planet Sustainable } \\
\text { Tourism Programme }\end{array}$ & Responsible tourism recovery & May-20 \\
\hline $\begin{array}{l}\text { World Bank (Twining Ward, L. } \\
\text { and McComb) }\end{array}$ & Opportunities for sustainable regional outcomes & Jun-20 \\
\hline SPTO & Recovery pathways for the South Pacific & June-20 \\
\hline UN & Opportunity for transforming tourism & Aug-20 \\
\hline McKinsey and Company & Reimagining the tourism economy & Aug-20 \\
\hline WITC & The future of travel and tourism & Sep-20 \\
\hline $\begin{array}{l}\text { Department of Tourism } \\
\text { Vanuatu }\end{array}$ & Safety and (economic) recovery responses & Sep-20 \\
\hline ABTA & Vision for tourism's positive impact & Oct-20 \\
\hline OECD & Policy response to support the aviation industry & Oct-20 \\
\hline ADB & Economic impact and future for tourism in the Maldives & Oct-20 \\
\hline PATA & Policy interventions to support tourism in Asia Pacific & Nov-20 \\
\hline Travalyst & A vision for the re-emergence of travel & Jan-21 \\
\hline OECD & Managing tourism recovery for sustainable outcomes & Jan-21 \\
\hline CAREC and ADB & $\begin{array}{l}\text { Impact of COVID- } 19 \text { on aviation in Central Asia Regional } \\
\text { Economic Cooperation countries }\end{array}$ & Feb-21 \\
\hline IMF & Economic challenges and opportunities for tourism & Feb-21 \\
\hline Tourism Futures Taskforce & A blueprint for the transformation of tourism in New Zealand & Feb-21 \\
\hline
\end{tabular}

VOL. 9 NO. 12023 JOURNAL OF TOURISM FUTURES| PAGE 37 
The analysis considered the phases of strategic foresight outlined by Postma and Yeoman (2021), including an assessment of the system as a whole, key drivers and uncertainties, and-in this casetheir materialisation as part of four plausible tourism trajectories within the broader envelopes of scenarios developed by Forum for the Future (2020). More specifically, the analysis involved keyword search of documents (Table 2) as well as a deductive thematic analysis (Braun and Clarke, 2006). The latter required identification of relevant codes, informed by existing theory, for example, codes were created to identify different system goals drawing on the concept of leverage points and transformation (see Loehr and Becken, 2021). Inherently, this process is a subjective one that depends on the interpretation of document intent and content by the researchers. It does align, however, with the constructivist interpretative paradigm (Lincoln and Guba, 2000) common to building and understanding scenarios. The work presented here formed part of a larger project on building-back-better for tourism, undertaken for the Asian Development Bank (ADB).

\section{Pathways and opportunities}

The following sections present a synopsis of how the four scenarios play out in the tourism context (see ADB, 2021). Relevant responses to COVID-19 and recommendations made by key organisations or governments are presented as supporting evidence of the respective trajectories. Each scenario presents different opportunities and risks for sustainable tourism. An overview of how the futures support the 17 SDGs is presented in Table 3 . It is important to note that sometimes it might be practically challenging to differentiate opportunities and risks, especially in the case of unintended consequences, and this requires further research (and monitoring) in the future.

\section{Scenario "discipline" - the age of technology}

\section{Tourism system goal and implications}

The Discipline scenario foresees a future with increased control by using digital technology, stricter protocols and enforcements of policies. It is akin to the control model described in Postma and Yeoman (2021). The goal in this scenario is to maintain economic growth and globalisation, embedded in the paradigm of capitalism. In this scenario, international travel will resume and return "back to normal". Whilst neoliberalism prevails in the context of market governance (Hall, 2011) and economic activity, an increasing involvement by state governments will become embedded in many non-economic domains.

The initial focus on maintaining public health and safety will be extended to make greater use of technology and standards elsewhere, including driving productivity. Standards increase

\section{Table 2 Four scenarios developed by Forum for the Future (2020) and keywords that} helped identify a scenario evoked in documents

\begin{tabular}{|c|c|c|}
\hline Scenario & Brief description & Keywords used \\
\hline Discipline & $\begin{array}{l}\text { Accelerated digitalisation and greater } \\
\text { control to manage the pandemic and future } \\
\text { disruptions to the economy. Use of } \\
\text { technology will support further growth and } \\
\text { efficiency }\end{array}$ & $\begin{array}{l}\text { Digital, automated, touch-free, electronic, } \\
\text { standard, certification, protocols }\end{array}$ \\
\hline $\begin{array}{l}\text { Compete and } \\
\text { Retreat }\end{array}$ & $\begin{array}{l}\text { Limited resources mean that countries } \\
\text { focus on their national priorities. Tourism } \\
\text { mobility will reduce to travel closer to home }\end{array}$ & $\begin{array}{l}\text { National, domestic, travel restrictions, local } \\
\text { supply chains, retreat, economic } \\
\text { diversification, exit, community }\end{array}$ \\
\hline Unsettled & $\begin{array}{l}\text { The world is strange and volatile beyond all } \\
\text { previous human experience. Tourism } \\
\text { recovery will experience several setbacks }\end{array}$ & $\begin{array}{l}\text { Climate change, extreme events, recession, } \\
\text { crisis, resilience, adaptation, risk } \\
\text { management }\end{array}$ \\
\hline Transform & $\begin{array}{l}\text { Planetary health and human wellbeing } \\
\text { come first. A major shift in mindset } \\
\text { transforms the way we "do tourism" }\end{array}$ & $\begin{array}{l}\text { Regeneration, restoration, ecological } \\
\text { integrity, community thriving, empowerment }\end{array}$ \\
\hline
\end{tabular}


Table 3 Key risks and opportunities for the scenarios in relation to the SDGs

\begin{tabular}{|c|c|c|c|c|c|}
\hline \multicolumn{2}{|c|}{$\begin{array}{l}\text { Key SDGs for } \\
\text { tourism }\end{array}$} & \multirow{2}{*}{$\begin{array}{l}\text { Discipline } \\
\text { Sacrifice of consumer privacy. } \\
\text { Lack of connectedness due to } \\
\text { touchless technologies. } \\
\text { Consumer data facilitates } \\
\text { tailored tourism experiences. }\end{array}$} & \multirow{2}{*}{\begin{tabular}{|l|} 
Compete and retreat \\
$\checkmark$ Greater community \\
cohesion may increase \\
subjective wellbeing.
\end{tabular}} & \multirow{2}{*}{ 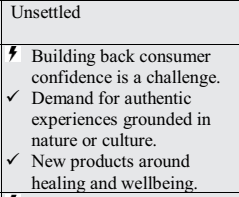 } & \multirow{2}{*}{\begin{tabular}{|l|} 
Transform \\
$\checkmark$ A greater focus on thriving \\
and well-being addresses \\
other issues, such as \\
biophysical and mental \\
health. \\
\end{tabular}} \\
\hline$-w_{0}^{3}$ & Wellbeing & & & & \\
\hline 5 & $\begin{array}{l}\text { Gender } \\
\text { equity }\end{array}$ & & & $\begin{array}{l}\text { Women will be affected } \\
\text { more and require special } \\
\text { support. }\end{array}$ & $\begin{array}{l}\text { Greater inclusion and } \\
\text { representation of diverse } \\
\text { voices. }\end{array}$ \\
\hline 7 & $\begin{array}{l}\text { Cleaner } \\
\text { energy }\end{array}$ & $\begin{array}{l}\checkmark \text { Digitally enabled grids are more } \\
\text { efficient. }\end{array}$ & $\begin{array}{l}4 \text { Countries revert to } \\
\text { national solutions rather } \\
\text { than global technology. }\end{array}$ & $\begin{array}{l}\text { Governments lack } \\
\text { resources to invest into } \\
\text { clean energy. }\end{array}$ & \\
\hline $\begin{array}{l}\text { Ti1 } \\
\text { growth }\end{array}$ & $\begin{array}{l}\text { Decent } \\
\text { work and } \\
\text { economic }\end{array}$ & $\begin{array}{l}\text { Loss of tourism jobs due to } \\
\text { increasing automation. } \\
\checkmark \text { Smarter systems can drive } \\
\text { operational efficiency. }\end{array}$ & $\begin{array}{l}4 \text { Growing gaps between } \\
\text { countries. } \\
\checkmark \text { Local supply chains } \\
\text { reduce leakage. } \\
\checkmark \text { Improved migrant } \\
\text { policies. }\end{array}$ & $\begin{array}{l}\text { Mounting economic } \\
\text { damage from multi-crises. } \\
\text { Destinations with closer } \\
\text { markets might benefit as } \\
\text { people are still holidaying. } \\
\checkmark \text { Increased focus on flexible } \\
\text { work arrangements. }\end{array}$ & $\begin{array}{l}\text { 4hose who are not able to } \\
\text { adapt to new models and } \\
\text { values are impacted. }\end{array}$ \\
\hline 8 & $\begin{array}{l}\text { Infra- } \\
\text { structure }\end{array}$ & $\begin{array}{l}\text { Major investment into digital } \\
\text { infrastructure is required, } \\
\text { possibly at the expense of other } \\
\text { investments. }\end{array}$ & $\begin{array}{l}4 \text { Limited exchange of } \\
\text { information, data and } \\
\text { knowledge will hamper } \\
\text { progress. }\end{array}$ & $\begin{array}{l}\text { Lack of funding for large } \\
\text { infrastructure projects. } \\
\text { Multipurpose approach to } \\
\text { tourism infrastructure } \\
\text { increases use value. }\end{array}$ & $\begin{array}{l}\checkmark \text { Increased funding for } \\
\text { environmentally friendly } \\
\text { infrastructure. }\end{array}$ \\
\hline 10 & $\begin{array}{l}\text { Reduced } \\
\text { inequalities }\end{array}$ & $\begin{array}{l}\checkmark \text { Digitalization can 'democratise' } \\
\text { information and mobility. } \\
\text { Disadvantage for some } \\
\text { countries, businesses or } \\
\text { travellers. }\end{array}$ & & & $\begin{array}{l}\text { The transition needs to be } \\
\text { managed well to ensure that } \\
\text { vulnerable groups are not left } \\
\text { behind. }\end{array}$ \\
\hline 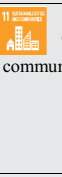 & $\begin{array}{l}\text { Sustainable } \\
\text { cities and } \\
\text { unities }\end{array}$ & $\begin{array}{l}4 \text { Increasing standardisation } \\
\text { erodes diversity. } \\
\checkmark \text { High resolution data can lead to } \\
\text { well-managed "smart } \\
\text { destinations". }\end{array}$ & $\begin{array}{l}\checkmark \text { Increased "localism" and } \\
\text { community resilience. } \\
\checkmark \text { Revival of cultural } \\
\text { practices and identity. }\end{array}$ & $\begin{array}{l}\checkmark \text { Ongoing crisis will } \\
\text { catalyse resilience } \\
\text { building. }\end{array}$ & $\begin{array}{l}\text { Not all countries are able to } \\
\text { transition away from high- } \\
\text { carbon or extractive } \\
\text { industries. } \\
\checkmark \text { Increased community } \\
\text { cohesion and empowerment } \\
\text { will lead to healthy and } \\
\text { resilient destinations. } \\
\end{array}$ \\
\hline consum & $\begin{array}{l}\text { Sustainable } \\
\text { production } \\
\text { and } \\
\text { nption }\end{array}$ & $\begin{array}{l}\checkmark \text { Digital systems can optimise } \\
\text { resource use at a network level. }\end{array}$ & $\begin{array}{l}\text { Competing approaches to } \\
\text { sustainability and multiple } \\
\text { standards that are } \\
\text { confusing to the } \\
\text { (international) consumer. }\end{array}$ & $\begin{array}{l}\text { Crisis forces actors into a } \\
\text { responsive pattern, eroding } \\
\text { sustainability. } \\
\checkmark \text { Resource scarcity fosters } \\
\text { greater efficiency. }\end{array}$ & $\begin{array}{l}\checkmark \text { An increase in demand for } \\
\text { sustainable experiences will } \\
\text { enhance business practices } \\
\text { and products. }\end{array}$ \\
\hline Q & $\begin{array}{l}\text { Climate } \\
\text { action }\end{array}$ & $\begin{array}{l}\checkmark \text { Virtual tourism may reduce } \\
\text { carbon footprints. }\end{array}$ & $\begin{array}{l}\checkmark \text { Local supply reduces } \\
\text { transport needs. } \\
\checkmark \text { Reduced aviation will lead } \\
\text { to lower emissions. }\end{array}$ & & $\begin{array}{l}\text { Rapid action on climate } \\
\text { change reduces the risk of } \\
\text { climate disasters and loss of } \\
\text { life and capital }\end{array}$ \\
\hline 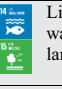 & $\begin{array}{l}\text { ife below } \\
\text { vater and on } \\
\text { and }\end{array}$ & $\begin{array}{l}\checkmark \text { Greater government control } \\
\text { could integrate sustainability } \\
\text { aspects into standards and } \\
\text { enforce compliance. }\end{array}$ & $\begin{array}{l}\checkmark \text { Strategic investment into } \\
\text { natural system. }\end{array}$ & & $\begin{array}{l}\checkmark \text { People enjoy a revival of } \\
\text { natural ecosystems, including } \\
\text { clean rivers and air, and } \\
\text { abundant wildlife. }\end{array}$ \\
\hline instituti & $\begin{array}{l}\text { Peace, } \\
\text { justice and } \\
\text { strong } \\
\text { tions }\end{array}$ & $\begin{array}{l}4 \text { Greater control of few might } \\
\text { undermine diversity and } \\
\text { empowerment. }\end{array}$ & & $\begin{array}{ll}4 & \text { Prioritising national } \\
\text { interests may disrupt } \\
\text { peace. } \\
\checkmark \\
\text { Investment into enhancing } \\
\text { destination governance and } \\
\text { local institutions. }\end{array}$ & $\begin{array}{l}\text { There might be opposition to } \\
\text { change. }\end{array}$ \\
\hline का & $\begin{array}{l}\text { Partner- } \\
\text { ships }\end{array}$ & $\begin{array}{l}\checkmark \text { Greater coordination between } \\
\text { countries around commonly } \\
\text { agreed standards. }\end{array}$ & & & \\
\hline
\end{tabular}

transparency for visitors, but also reduce choices. In practice, governments will rapidly invest into new digital systems and capability, and coordinate these with major trading partners. This yields vast volumes of data on every aspect of life, raising questions around privacy and surveillance for consumers. This has also implications on business training and greater emphasis of computing science (and big data) in high school or university curricula. The data and machine-driven approach to tourism is likely to fundamentally change the travel experience, including how people connect with each other and the environment. For example, greater use of digital meeting technology has the potential to profoundly change patterns of tourism demand, including for business travel (Becken and Hughey, 2021).

\section{Evidence from pandemic}

Many of the early pandemic recommendations lay the foundation for a Discipline trajectory, in particular relating to the question who is allowed to travel. Examples include digital health passports, tracking of vaccination or COVID-19 test results and COVID-19 tracing apps (WTTC, 2020). Whilst some of these tools aim to build confidence, improve transparency and allow freedom of movement for travellers, they also exacerbate inequalities. These may arise where individuals are not able to access health treatments and vaccination, or because some regions are 
not able to provide it. The UN (2020) and WTTC (2020) recommend that governments prioritise investment into digital innovation, infrastructure (i.e. Internet) and capability (SDG\#9). Some countries lack the necessary resources, and which case partnerships between governments and large tourism companies could assist (Travalyst, 2021). The balance between health on the one hand (SDG\# 3) and reducing inequality (SDG\#10) sits at the core of this digitisation development.

Digitisation is also increasing at the business-level. Since the beginning of the pandemic, $67 \%$ of small and medium-sized enterprises (SMEs) globally have engaged in e-commerce to ensure continuation of business activity (based on Visa survey, Travalyst, 2021). For the case of the tourism-dependent Maldives, ADB (2020) recommended to specifically support the digital capability of SMEs. Recommendations for increased investment into touchless technology made by UN (2020), such as voice control and electronic check-ins, will contribute to the system moving along the Discipline trajectory. Implications for visitors (e.g. feelings of loneliness, lack of connectedness to destination) and the workforce (e.g. loss of jobs) need to be managed carefully (i.e. SDG\#3 on wellbeing). Policies are required to sustain reasonable levels of human-to-human contact in tourism and maintain the required soft people skills to provide this (SDG\#8 on decent work). Given rapid increase in digitisation, WTTC (2020) recommended to upskill all tourism actors and organisations on cybersecurity risks (WTTC, 2020).

Agreed standards and protocols play an important part in the Discipline scenario. Several organisations proposed greater coordination around hygiene and health standards as part of the COVID-19 recovery, including the UNWTO (2021) and the World Bank (Twining Ward and McComb, 2020). The Department of Tourism Vanuatu (2020) set a target of 90\% of tourism businesses being health audited by December 2020. Tourism-specific hygiene standards have already been developed in and are being implemented and verified, for example, the COVID-Ready standard by Hotel Resilient, the WTTC's Safe Travels health and hygiene global protocols, and EarthCheck's EarthSafe certification. The International Monetary Fund (IMF) suggested increased tourism opportunities around wellness tourism in countries that have already invested in related infrastructure and services (IMF, 2021). The focus on centrally controlled standards brings opportunities for strengthening sustainability performance (e.g. SDG\#12 on sustainable production) and reducing environmental impacts (SDGs\#13, 14, 15). Smart technology could become a key tool in educating guests and staff, and change behaviours (Warren et al., 2016).

All of the above entails a great volume of tourism data and statistics (e.g. OECD, 2020; Twining Ward and McComb, 2020), and many countries have already invested in market intelligence to mine these to better respond to rapid changes in demand (see recommendation by UNWTO, 2021). Given the risks and ethical concerns (Gretzel et al., 2020) associated with data and digitisation, ILO (2020) recommended that it is important that tourism data collection occurs in "social dialogue" with employers and workers. Whilst managing those concerns, the collection of high-resolution tourism data presents an opportunity to deliver on SDG\#12, as proposed by One Planet Sustainable Tourism Programme (2020, p. 11):

Generating regular and timely data to support decision making towards sustainability in tourism is crucial for the recovery to be aligned with ambitions on resource efficiency, climate change and biodiversity as well as to ensure that the needs of host communities, including public health, are well integrated in destination management.

\section{Scenario "compete and retreat" - the end of globalisation? Tourism system goal and implications}

The Compete and Retreat trajectory comes with strengthened nationalism and a decline of global approaches and solidarity. National interests will dominate in this trajectory and borders remain controlled tightly. Countries will make investments into self-sufficiency, for example, to address issues of energy security. If countries continue to invest in innovation and entrepreneurship, there is potential for transformation, including towards sustainability (Schumpeter, 1942; Rahdari et al., 2016). The way this scenario unfolds for each country depends strongly on the political system and 
the values that underpin it (e.g. social justice versus competition, state control versus community empowerment) (Amore and Hall, 2016). The goal in this future is to maintain stability within countries.

The main form of tourism will be domestic travel, and for countries such as China that ran large deficits on their tourism accounts pre-COVID, this will represent a net gain. Not every country has the same access to a domestic or regional market, and as a result, tourism in some destinations will shrink. Governments will take greater control of tourism, either to grow domestic markets or diversify away from tourism. Whilst tourism businesses redefine themselves and their products, they have to develop new partnerships as a result of nationalised supply chains. Destinations will develop visitor experiences centred around local products and services. As a result, feelings of unity and community cohesiveness might increase, but travellers have reduced choice regarding "exotic" destinations. As global trade slows, countries that are less endowed with natural resources may face difficulties, and this could lead to unsustainable practices (e.g. use of coal). However, reduced international travel and trade will lower global emissions from transportation.

\section{Evidence from pandemic}

Many of the immediate COVID-19 responses reflected the Compete and Retreat trajectory. This was evident as countries closed borders and prioritised national citizens, for example, on repatriation flights. Governments secured vaccines for their own people and supported national companies and "anchor businesses" (OECD, 2020). In the case of airline bailouts (e.g. CAREC and ADB, 2021), this has potentially adverse impacts on emissions (SDG\#13) when support comes without environmental conditions (UN, 2020). In response to closed borders, governments are faced with changing labour markets, with many countries lacking tourism workforce, and others having to deal with foreign workers returning to their home countries. The ILO (2020, p. 16) recommends for governments to consider "effective return and reintegration policies for migrant workers" to avoid conflict and reduce uncertainty.

Recommendations to promote domestic tourism were made by PATA (2020) and CAREC and ADB (2021), amongst others, to upkeep some economic activity (SDG\#8). The Thailand government, for example, invested $\$ 700 \mathrm{~m}$ to incentivise domestic tourism (IMF, 2021) and several countries, including the Indonesian government, subsidised domestic flights to selected destinations to encourage domestic travel (UNEP, IMF and GIZ, 2020). The government of Fiji-a country with a limited domestic market-has invested into a domestic campaign to stimulate tourism consumption and enable business re-entry into the market. This is subsidised through the removal of the $6 \%$ Service Turnover Tax and the reduction of the Environment and Climate Adaption Levy (UNWTO, 2021). The latter is a risky decision in that it undermines long-term climate change goals (SDG\#13) for short-term recovery. A similar tradeoff was observed in Australia where domestic flights were subsidised to induce travel (ABC, 2021). Investments into greener transport networks would be more conducive to sustainable outcomes.

As governments turn inwards, the World Bank advised to focus investment onto government services and strategic assets, including domestic attractions or natural systems (e.g. Twining Ward and McComb, 2020). An emphasis on natural capital would ensure this future delivers on the SDGs, for example, protecting oceans (\#14) and land (\#15). New Zealand's investment into "Jobs for Nature" (Ministry for the Environment, 2020) and the recognition of Aotearoa whakapapa (connection between people and place in New Zealand) (Tourism Futures Taskforce, 2021) are pertinent examples. Similarly, ABTA (2021) recommended focussing on generating benefits from tourism for local people, for example, by shifting towards local procurement and reducing economic leakage (see also UN, 2020). The increasing demand for locally produced food-and experiences such as agri-tourism-is also recognised by One Planet Sustainable Tourism Programme (2020). Further opportunities lie in greater inter-industry linkages, local engagement and community flourishing (Travalyst, 2021). 
National approaches can extend regionally, as for example, evidenced in the South Pacific Tourism Organisation's (SPTO) (2020) recovery pathways or through "travel bubbles". In either case, the IMF (2021) recommends close coordination among different tourism industries and the health sector so to ensure travel does not compromise safety. This resonates with calls by the OECD (2021) for an "integrated policy-industry-community approach" (p. 5). Either way, consumers in the Compete and Retreat scenario will have to adapt their holiday expectations to a less globalised world. International travel might be reserved to small elite, as explored in Yeoman et al.'s (2015) Eco-Paradise scenario for New Zealand.

\section{Scenario "unsettled" - crisis as the new normal}

\section{Tourism system goal and implications}

This future is defined by the ongoing impact of crisis and uncertainty rather than a particular mindset or system goal. The trajectory will be heavily impacted by ongoing shocks, including those related to resource scarcity, economic depression, extreme climatic events and conflict. Governments may not see tourism as a priority as existential crises affect their constituents and communities. Targeted action towards the SDGs will also become challenging, despite accelerating environmental collapse. Larger infrastructure projects might be difficult to fund, undermining the opportunity to develop some forms of tourism (e.g. large convention centres for business travel).

The uncertainty associated with such a volatile world will present a major challenge for the travel industry. Economically and psychologically, people will be less inclined to engage in tourism, and travellers' confidence will be damaged by insufficient vaccination success, mutations and setbacks in opening up borders. What will determine success in future markets will not be the size, strength or wealth of tourism businesses, but their adaptive capacity. This also involves high levels of agility tourism workforce; something that will be fostered in modified education and training plans. Thus, the goal for tourism in this future is one of maximising resilience and adaptability.

\section{Evidence from pandemic}

High public sector debt presents a major challenge, especially when more and more "safety nets" are required to protect the population (ADB, 2020). Several organisations highlighted the need to increase the resilience of tourism, not only to pandemics but to other risks. The OECD $(2021$, p. 31) recommends a "periodic review of jurisdictional responsibilities to ensure flexibility in the system, and to further strengthen institutional capacity at destination level". Strengthening tourism governance is important to increase the sector's ability to "bolster resilience and facilitate faster rebound" (Twining Ward and McComb, 2020, p. 11). A central "nerve centre" for tourism could facilitate collaborative decision-making (McKinsey and Company, 2020) and integration of key actors (OECD, 2021). To provide effective responses to reoccurring crisis, international cooperation will become even more important.

At this point, the pandemic has demonstrated that some tourism businesses were able to define themselves, for example, by repurposing their facilities to accommodate health workers, homeless people or people in quarantine. The Unsettled scenario could see building standards that mandate a multi-purpose approach through the concept of "adaptable buildings" (Manewa et al., 2016), contributing to SDGs\#9, 11. Recommended diversifications also refer to products, destinations and economic structures. This will be more challenging for destinations with a limited resource bases, such as island states (see ADB, 2020; SPTO, 2020). This will be challenging in a multihazard environment. At the end of 2020, for example, Fiji was struck by several severe cyclones whilst still responding to the COVID-19 pandemic through border closures. Destination risk assessments should be undertaken as part of an early warning system (UN, 2020). In multi-hazard environments with "limits to adaptation" (Espiner and Becken, 2014), exit strategies might become the only option. 
Transforming business models, for example, through remote and flexible work arrangements, has been proposed by the ILO (2020). Tourism workers were able to be deployed in other sectors due to the transferability of their skills, for example, Singapore Airline staff were recruited as health workers (The Straits Times, 2020). Examples of pivoting to new services include delivering meals to people in isolation, selling products at local markets, or providing educational tours to schools. To enable a more resilient business and worker environment (SDG\#8 and women in particular SDG\#5), new policy frameworks are required (UN, 2020). In this volatile future, it is important to ensure that the most vulnerable workers are protected, and existing gaps are not further exacerbated. The Department of Vanuatu (2020, p. 14) summed this up in their goal

to finalize and roll out the Tourism Industry support program to address the issue of equitable growth and prosperity, investment in green infrastructure, addressing the issue of sector inclusiveness, diversification and remodelling of business models and ensuring capacity through institutional strengthening.

Protecting those who still choose to travel will be increasingly necessary in this volatile future. Recommendations include increasing the flexibility of travel arrangements, loosening cancellation policies and adjusting travel insurance (WTTC, 2020). Consumer research by Trip.com (in Travalyst, 2021) shows that $57 \%$ of travellers consider penalty-free cancellation policies as important elements at the time of booking.

\section{Scenario "transform" - a shift in mindset}

\section{Tourism system goal and implications}

The Transform future reflects the largest shift in mindset and economic system, across all elements of the tourism system. In this scenario, action shapes the trajectory towards a more sustainable, low carbon, fair and equitable world. This requires transitioning away from exploitative practices to regenerative ones (Pollock, 2019). As described by the Forum for the Future (2020, p. 44) "For a company that serves society, profit is the means, not the goal in itself. Wellbeing is a measure of success, and so is resilience. Inequality is not a by-product of the system but a metric of failure". Transforming tourism requires considerable effort across all scales, local, national, regional and global-often with resistance by existing system dynamics, institutions and actors (Becken, 2019). Polycentric governance arrangements will help manage resources and conflicts effectively (Amore and Hall, 2016), with collective action involving all types of actors, including civil society. The Transform narrative focuses on changes in the system goal towards social justice (Rastegar et al., 2021), degrowth (Higgins-Desbiolles et al., 2019), regeneration and system healing (Pollock, 2019). Hartman et al. (2020, p. 215) recognise the potential that "tourism is an integral part of strategic and inclusive spatial planning and placemaking, aimed at creating good places to live and good places to visit." Taking a whole-of-system perspective constitutes the core assumption in this future (Loehr et al., 2020).

\section{Evidence from pandemic}

There is some evidence for the Transform trajectory. New Zealand Tourism Futures Taskforce (2021) and its 21 recommendations recognised that a whole-of-system change is required to achieve a future state of regenerative tourism. At the heart of this lies an economic reform, including addressing external costs and transitioning to circularity (zero waste) (OECD, 2020). The UN (2020) recommended that any public sector investment should come with attach sustainability criteria and policy should be science-based (SDGs\#12, 13). ABTA (2021) advocated for greater investment into the measurement of tourism sustainability, including a complete new set of indicators, according to OECD (2021).

All of these can be supported through intragovernmental and intergovernmental cooperation, coordination and collaboration. Finance and funding for more environmentally friendly tourism infrastructure will be critical in the Transform scenario (SDG\#9). As an immediate response to the 
COVID-19 crisis, the Ministry of Environment and Tourism in Mongolia, for example, has lowered the interest rates for its "Green Loan" scheme. Initiatives support sustainable heating, wastewater and accommodation businesses. To ensure sustainable recovery, the One Planet Sustainable Tourism Programme (2020, p. 11) proposed that "innovative financing solutions and blended public private approaches would be needed". To address one of the most pressing issues, the OECD (2020) recommended investing into sustainable aviation fuels, but at the same time also advises a modal shift from air to rail where possible. Exit strategies for high emitters may need to be provided. OECD (2021) also suggested that finance should be coupled with other instruments that disincentivise unsustainable business models. Instead, the Transform scenario encourages social entrepreneurship, including, for example, through social enterprises.

At the local level, the WTTC (2020, p. 37) emphasised the role of "destination stewardship [. . . to drive action for preservation of cultural and natural assets". Building local partnerships, growing community capability and investing in place-based projects that reflect local voices have multiple benefits. Enhancing diversity and inclusiveness in tourism (including minority groups, WTTC, 2020) are important elements of this future. This also involves equality, in particular in relation to gender (SDG\#5), which continues to be a challenge in tourism (Rastegar et al., 2021). Denmark for example allocated recovery funds to incentivise arts and cultural activities for vulnerable elderly citizens to reduce loneliness and at the same time support a sector suffering from reduced tourist numbers (UNEP, IMF and GIZ, 2020).

Reinvesting into nature is another priority in this future (Tourism Futures Taskforce, 2021). There are short-term opportunities to raise funds from tourism towards carbon sequestration and forest restoration (e.g. addressing both SDGs\#13,15). Such initiatives could also deliver on economic SDGs when linked to local ecotourism livelihoods. Investing into nature-based solutions increases system resilience (Loehr et al., 2020). With regard to particularly vulnerable ecosystems, such as coral reefs, there is a clear role for tourism. Westoby et al. (2020) found, for example, that coral restoration projects that involve tourism operators are financially more sustainable than those that depend on external grants alone. They also provide an opportunity to engage visitors in volunteer activities; enabling them to reconnect to nature in ways that are central to the Transform scenario.

\section{Conclusion}

The future for tourism after COVID-19 is still uncertain, making it extremely difficult for those involved in the tourism system (e.g. governments, businesses and other actors) to plan ahead. Crisis is often a time for change, if not transformation-but this depends on many factors, including how a particular policy challenge is approached (Amore and Hall, 2016; Nalau and Handmer, 2015). This paper explored pathways for system change and how COVID-19 response measures contribute to shaping the tourism system's trajectory. Narratives for four future scenarios were presented, drawing on work by the Forum for Future and Travalyst and extending it to tourism in the Asia Pacific region with a particular focus on coronavirus response and recovery policies. The four scenarios reflect different system goals (Meadows, 2008), and this has implications for their potential to increase tourism's ability to contribute to sustainable development. The findings presented here are relevant for tourism decision-makers with a particular focus on Asia Pacific, and inform the development of tourism's adaptability in the face of uncertainty and complexity.

The Discipline scenario's goal is to enable tourism growth to maximise economic impact. As such it meets the characteristics of the "resistance and maintenance" change type discussed in Nalau and Handmer's (2015) study. The Retreat and Compete scenario represents the "change at the margins" type, as the system goal has moved from pre-COVID-19 growth to maintaining national stability. Both the Unsettled and Transform scenarios reflect "transformation" in Nalau and Handmer's typology because of the high uncertainty and significant changes required in all parts of the system. The Transform future might be most challenging for decision-makers, as it involves proactive change of key levers and this might upset existing elites (see Becken, 2019) who seek to prevent more profound redistribution of resources and authority (Amore and Hall, 2016). 
Notwithstanding some resistance, the Transform scenario aims for regeneration and thriving of humankind in harmony with nature. It specifically embraces a systems approach to tourism (e.g. Loehr et al., 2020) and recognises the need to address all SDGs simultaneously and in an integrated fashion (Nash et al., 2020). Understanding the (quite different) system goals of the four plausible scenarios is useful for decision-makers, because goals influence governance arrangements, and these drive policy decisions, and ultimately determine choice of performance indicators and measurement of success. Understanding this cascade increases the effectiveness of interventions and helps develop a new "economic narrative" (OECD, 2018).

To provide an initial assessment of how early pandemic responses and recommendations might shape the trajectory of Asia Pacific tourism, 17 documents and two data bases were analysed for evidence of either of the four futures. The findings highlight that current recovery policies are diverse; however, the overall tourism COVID-19 recovery is mostly framed as building traveller confidence, fostering economic growth and a return to "normal". Thus, the current dynamics are moving the system trajectory according to the Discipline scenario. There is some evidence towards national approaches (i.e. Compete and Retreat), but these could be temporary depending on vaccine success. There are notable examples that point towards the Transform scenario. Both New Zealand and Vanuatu have placed a distinct focus on wellbeing and natural capital in their COVID-19 recovery strategies. Being embedded in a global tourism system, it remains to be seen whether individual countries can maintain substantially different trajectories. It is too early to tell whether tourism will ultimately follow the Unsettled path, although recent extreme climate events highlight the precariousness of the planetary system, and by consequence most tourist destinations (Scott, 2021). The precautionary principle should guide pandemic responses, and lead to the adoption of a longer-term multi-risk approach.

Some policy recommendations revealed a conflict, for example, between maintaining public health and ensuring individual freedom and privacy. Another example pertinent to sustainability is the short-term support of airlines that will hinder climate mitigation in the future. This is a considerable risk as recovery responses can lock the system into a trajectory that prevents future adaptability and transformation (Moyle et al., 2017). Despite these trade-offs, the research shows that each scenario contains unique opportunities for SDG support. These need to be capitalised on proactively, whilst also managing the risks identified in Table 3. With the long-term in mind, enhancing sustainability is a safe strategy. Tourism's recovery will therefore benefit from response strategies that foster sustainability, which means that sustainability should become the universal, cross-cutting goal for the recovery of the tourism system.

\section{References}

ABC (2021), "Half-price flights on offer as Government asks Australians to holiday for cheap at home", 11th March, available at: https://www.abc.net.au/news/2021-03-10/tourism-coronavirus-pandemic-assistancepackage-cheap-flights/13235432.

ABTA (2021), "Tourism for good", available at: https://www.abta.com/sites/default/files/media/document/ uploads/ABTA\%20Tourism\%20for\%20Good\%20A5\%20Booklet\%20121020.pdf.

ADB (2020), Maldives Economic Update 2020, Manila, available at: https://www.adb.org/sites/default/files/ institutional-document/674971/maldives-economic-update-2020.pdf.

ADB (2021), "Sustainable tourism after COVID-19: insights and recommendations for Asia and the Pacific", Manila, available https://www.adb.org/publications/sustainable-tourism-after-covid-19-insightsrecommendations.

Amore, A. and Hall, C.M. (2016), "From governance to meta-governance in tourism? Re-incorporating politics, interests and values in the analysis of tourism governance", Tourism Recreation Research, Vol. 41 No. 2, pp. 109-122.

Assaf, A. and Scuderi, R. (2020), "COVID-19 and the recovery of the tourism industry", Tourism Economics, Vol. 26 No. 5, pp. 731-733, doi: 10.1177/1354816620933712.

Becken, S. (2019), "Decarbonising tourism: mission impossible?”, Tourism Recreation Research, Vol. 44 No. 4, pp. 419-433. 
Becken, S. and Hughey, K.F. (2021), "Impacts of changes to business travel practices in response to the COVID-19 lockdown in New Zealand", Journal of Sustainable Tourism, Vol. 30 No. 1, pp. 108-127, doi: 10. 1080/09669582.2021.1894160.

Braun, V. and Clarke, V. (2006), "Using thematic analysis in psychology”, Qualitative Research in Psychology, Vol. 3 No. 2, pp. 77-101, doi: 10.1191/1478088706qp063oa.

Buckley, R., Gretzel, U., Scott, D., Weaver, D. and Becken, S. (2015), "Tourism megatrends", Tourism Recreation Research, Vol. 40 No. 1, pp. 59-70.

CARECADB (2021), "Impact of COVID-19 on CAREC aviation and tourism", February 2021. Available at: https://www.adb.org/sites/default/files/publication/674106/impact-covid-19-carec-aviation-tourism.pdf.

Department of Tourism Vanuatu (2020), "Phase 1: response. Immediate safety, response and economic recovery effort", available at: https://tourism.gov.vu/index.php/about/reports-plans-policies/reports/recovery-plan-p1.

Espiner, S. and Becken, S. (2014), "Tourist towns on the edge: conceptualising vulnerability and resilience in a protected area tourism system", Journal of Sustainable Tourism, Vol. 22 No. 4, pp. 646-665.

Forum for the Future (2020), "From system shock to system change: time to transform. The future of sustainability", available at: https://www.forumforthefuture.org/new-report-out-now-from-system-shock-tosystem-change-its-time-to-transform.

Gjaltema, J., Biesbroek, R. and Termeer, K. (2020), "From government to governance...to metagovernance: a systematic literature review”, Public Management Review, Vol. 22 No. 12, pp. 1760-1780.

Glass, L. and Newig, J. (2019), "Governance for achieving the Sustainable Development Goals: how important are participation, policy coherence, reflexivity, adaptation and democratic institutions?", Earth System Governance, Vol. 2, p. 100031

Gretzel, U., Fuchs, F., Baggio, R., Hoepken, W., Law, R., Neidhardt, J., Pesonen, J., Zanker, M. and Xiang, Z. (2020), "E-Tourism beyond COVID-19: a call for transformative research", Information Technology and Tourism, Vol. 22, pp. 187-203.

Hall, C.M. (2011), "A typology of governance and its implications for tourism policy analysis", Journal of Sustainable Tourism, Vol. 19 Nos 4-5, pp. 437-457.

Hall, C.M. (2019), "Constructing sustainable tourism development: the 2030 agenda and the managerial ecology of sustainable tourism", Journal of Sustainable Tourism, Vol. 27 No. 7, pp. 1044-1060.

Hartman, S., Wielenga, B. and Heslinga, J.H. (2020), "The future of tourism destination management: building productive coalitions of actor networks for complex destination development", Journal of Tourism Futures, Vol. 6 No. 3, pp. 213-218, doi: 10.1108/JTF-11-2019-0123.

Higgins-Desbiolles, F. (2021), "The 'war over tourism': challenges to sustainable tourism in the tourism academy after COVID-19”, Journal of Sustainable Tourism, Vol. 29 No. 4, pp. 551-569.

Higgins-Desbiolles, F., Carnicelli, S., Krolikowski, C., Wijesinghe, G. and Boluk, K. (2019), "Degrowing tourism: rethinking tourism", Journal of Sustainable Tourism, Vol. 27 No. 12, pp. 1926-1944.

ILO (2020), "COVID-19 and employment in the tourism sector: impact and response in Asia and the Pacific", available at: https://www.ilo.org/wcmsp5/groups/public/-asia/-ro-bangkok/documents/briefingnote/ wcms_742664.pdf.

IMF (2021), "Tourism in the post-pandemic world economic challenges and opportunities for asia-pacific and the western hemisphere", available at: https://www.imf.org/en/Publications/Departmental-Papers-PolicyPapers/Issues/2021/02/19/Tourism-in-the-Post-Pandemic-World-Economic-Challenges-andOpportunities-for-Asia-Pacific-49915.

Lincoln, Y. and Guba, E. (2000), Handbook of Qualitative Research, Sage, California.

Loehr, J. and Becken, S. (2021), "Leverage points to address climate change risk in destinations", Tourism Geographies. doi: 10.1080/14616688.2021.2009017.

Loehr, J., Becken, S., Nalau, J. and Mackey, B. (2020), "Exploring the multiple benefits of ecosystem-based adaptation in tourism for climate risks and destination well-being", Journal of Hospitality and Tourism Research. doi: 10.1177/1096348020944438.

Manewa, A., Siriwardena, M., Ross, A. and Madanayake, U. (2016), "Adaptable buildings for sustainable built environment”, Built Environment Project and Asset Management, Vol. 6, pp. 139-158, doi: 10.1108/BEPAM10-2014-0053. 
McKinsey and Company (2020), "Reimagining the \$9 trillion tourism economy - what will it take?", available at: https://www.mckinsey.com/ /media/McKinsey/Industries/Travel\%20Transport\%20and\%20Logistics/ Our\%2Olnsights/Reimagining\%20the\%209\%20trillion\%20tourism\%20economy\%20what\%20will\%20it\% 20take/Reimagining-the-9-trillion-tourism-economy_what-will-it-take-vF.pdf.

Meadows, D.H. (2008), in Wright, D.J. (Ed.), Thinking in Systems: A Primer, Chelsea Green Publishing, Vermont.

Ministry for the Environment (2020), "Jobs for nature", available at: https://environment.govt.nz/whatgovernment-is-doing/key-initiatives/jobs-for-nature/\#: :text=In\%20response\%20to\%20the\%20COVID, environment)\%20and\%20New\%20Zealand's\%20communities.

Moyle, C., Moyle, B. and Becken, S. (2017), "A multi-sectoral model of tourism and resource sector transformation", Tourism Recreation Research, Vol. 42 No. 4, pp. 422-435.

Nalau, J. and Handmer, J. (2015), "When is transformation a viable policy alternative?", Environmental Science and Policy, Vol. 54, pp. 349-356.

Nash, K.L., Blythe, J.L., Cvitanovic, C., Pecl, G.T., Watson, R.A. and Blanchard, J.L. (2020), "To achieve a sustainable blue future, progress assessments must include interdependencies between the sustainable development goals", One Earth, Vol. 2, pp. 161-173.

O'Brien, K. (2012), “Global environmental change II: from adaptation to deliberate transformation”, Progress in Human Geography, Vol. 36 No. 5, pp. 667-676, doi: 10.1177/0309132511425767.

OECD (2018), "Elements for a new growth narrative", Draft Report. SG/NAEC(2018)1, available at: https:// www.oecd.org/naec/SG_NAEC(2018)1_Elements\%20for\%20a\%20new\%20growth\%20narrative.pdf.

OECD (2020), "COVID-19 and the aviation industry: impact and policy responses", Published 15th October. Available at: http://www.oecd.org/coronavirus/policy-responses/covid-19-and-the-aviation-industry-impactand-policy-responses-26d521c1/.

OECD (2021), Managing Tourism Development for Sustainable and Inclusive Recovery, OECD Tourism Papers, 2021/01, OECD Publishing, Paris, doi: 10.1787/b062f603-en.

One Planet Sustainable Tourism Programme (2020), One Planet Vision for a Responsible Recovery of the Tourism, Madrid, available at: https://webunwto.s3.eu-west-1.amazonaws.com/s3fs-public/2020-06/oneplanet-vision-responsible-recovery-of-the-tourism-sector.pdf.

PATA (2020), "COVID-19 and the tourism sector: a comparison of policy response in Asia pacific", Published 12th November 2020, available at: https://crc.pata.org/covid-19-and-the-tourism-sector-a-comparison-ofpolicy-responses-in-asia-pacific/.

Patterson, J., Schulz, K., Vervoort, J., Adler, C., Hurlbert, M., van der Hel, S., Schmidt, A., Barau, A., Obani, P., Sethi, M., Hissen, N., Tebboth, M., Anderton, K., Börner, S. and Widerberg, O. (2015), 'Transformations towards Sustainability'. Emerging Approaches, Critical Reflections, and a Research Agenda, Earth System Governance, Working Paper No. 33, Earth System Governance Project, Lund and Amsterdam.

Pollock, A. (2019), Regenerative Tourism: the Natural Maturation of Sustainability, Linkedln, $2^{\text {nd }}$ October, available at: https://www.linkedin.com/pulse/regenerative-tourism-natural-maturation-anna-pollock/? trackingld=vKRZutcionTRjYPBhfCXPg\%3D\%3D.

Postma, A. and Yeoman, I.S. (2021), "A systems perspective as a tool to understand disruption in travel and tourism”, Journal of Tourism Futures, Vol. 7 No. 1, pp. 67-77.

Rahdari, A., Sepasi, S. and Moradi, M. (2016), "Achieving sustainability through Schumpeterian socialentrepreneurship: the role of social enterprises", Journal of Cleaner Production, Vol. 137, pp. 347-360.

Rastegar, R., Higgins-Desbiolles, F. and Ruhanen, L. (2021), "COVID-19 and a justice framework to guide tourism recovery", Annals of Tourism Research, p. 103161, doi: 10.1016/j.annals.2021.103161.

Schumpeter, J.A. (1942), Capitalism, Socialism and Democracy, Harper \& Row, New York.

Scott, D. (2021), "Sustainable tourism and the grand challenge of climate change", Sustainability, Vol. 13, p. 1966, doi: 10.3390/su13041966.

SPTO (2020), "Pacific tourism: covid-19 impact and recovery. Scenario development and recovery pathways: report", available at: https://www.mfat.govt.nz/assets/Aid-Prog-docs/Evaluations/2020/PacificTourism-Sector-scenario-development-and-recovery-pathways-SPTO-FINAL-PDF-10062020.pdf.

The Straits Times (2020), "SIA cabin crew redeployed to care for hospital patients", 8th April, available at: https:// www.straitstimes.com/singapore/manpower/sia-cabin-crew-redeployed-to-care-for-hospital-patients.

VOL. 9 NO. 12023 JOURNAL OF TOURISM FUTURES $\mid$ PAGE 47 
Tourism Futures Taskforce (2021), "We are Aotearoa”, available at: https://www.mbie.govt.nz/immigrationand-tourism/tourism/tourism-recovery/tourism-futures-taskforce.

Travalyst (2021), "The Re-emergence of travel: a Travalyst view", available at: https://travalyst.org/the-reemergence-of-travel/.

Twining Ward, L. and McComb, J.F. (2020), COVID-19 and Tourism in South Asia: Opportunities for Sustainable Regional Outcomes, World Bank, Washington, DC, available at: https://openknowledge. worldbank.org/handle/10986/34050.

UN (2020), "COVID-19 and transforming tourism", available at: https://unsdg.un.org/resources/policy-briefcovid-19-and-transforming-tourism.

UNEP, IMF and GIZ(2020), "COVID-19: measures to support travel and tourism", available at: https:// greenfiscalpolicy.org/observatory/.

UNWTO (2021), "COVID-19: measures to support travel and tourism", available at: https://www.unwto.org/ covid-19-measures-to-support-travel-tourism.

UNWTO and UNEP (2017), Tourism and the Sustainable Development Goals - Journey to 2030, Highlights, UNWTO, Madrid, doi: 10.18111/9789284419340.

Warren, C., Becken, S. and Coghlan, A. (2016), "Using persuasive communication to co-create behavioural change - engaging with guests to save resources at tourist accommodation facilities", Journal of Sustainable Tourism, Vol. 25 No. 7, pp. 935-954.

Westoby, R., Becken, S. and Laria, A.P. (2020), "Perspectives on the human dimensions of coral restoration", Regional Environmental Change, Vol. 20 No. 4, p. 109, doi: 10.1007/s10113-020-01694-7.

WTTC (2020), "To Recovery and Beyond: the future of travel and tourism in the wake of COVID-19", available at: https://wttc.org/Research/To-Recovery-Beyond/moduleld/1707/itemld/182/controller/DownloadRequest/ action/QuickDownload.

Yeoman, I., Palomino-Schalscha, M. and McMahon-Beattie, U. (2015), "Keeping it pure: could New Zealand be an eco paradise?", Journal of Tourism Futures, Vol. 1 No. 1, pp. 19-35.

\section{About the authors}

Susanne Becken is Professor of Sustainable Tourism at Griffith University in Australia and the Principal Science Investment Advisor (Visitor) in the Department of Conservation, New Zealand. She is also a Vice Chancellor Research Fellow at the University of Surrey in the United Kingdom. Susanne is a Fellow of the International Academy of the Study of Tourism and the 2019 UNWTO Ulysses Award winner. Susanne Becken is the corresponding author and can be contacted at: s.becken@griffith.edu.au

Johanna Loehr is a post-doctoral research fellow at the Griffith Institute for Tourism, Griffith University, Australia. Johanna has extensive experience in the development of research tools, data collection and analysis having worked on several research projects on tourism and climate change, including the Pacific EcoAdapt project, a Water for Women Fund project on engaging hotels in improving water, sanitation and hygiene and a range of consulting projects on sustainable tourism.

For instructions on how to order reprints of this article, please visit our website: www.emeraldgrouppublishing.com/licensing/reprints.htm Or contact us for further details: permissions@emeraldinsight.com 